\title{
CYANOPHYCEAN ALGAE INHABITING SODIC SOIL EXHIBIT DIVERSE MORPHOLOGY: AN ADAPTATION TO HIGH EXCHANGEABLE SODIUM
}

\author{
P.K. Singh, S. Kishore, J. Prakash, S.K. Singh and M. Shukla \\ Department of Botany \\ University of Lucknow, Lucknow-226007, India
}

\begin{abstract}
A soil pot experiment was conducted in soils containing two exchangeable sodium percentage (ESP) levels i.e. normal (4.37) and high (54.5) ESP levels. The soils used in experiment were collected from different natural conditions to asses the algal biodiversity and changes in morphology of algae. The genera reported at high ESP were Oscillatoria, Lyngbya and colony of Anabaena while in normal soil these were absent. The heterocyst chain was also observed in soil of high ESP while in normal soil it was not reported. The width of heterocyst was much different than those reported. The chemical properties of soil e.g. $\mathrm{pH}$, exchangeable sodium and ESP were decreased while organic carbon and total nitrogen contents were increased after one year algal growth.
\end{abstract}

Key words: Cyanophycean algae, heterocyst, sodic soil, exchangeable sodium percentage.

\section{INTRODUCTION}

Environmental constraints including salinity and alkalinity significantly influence the diversity of micro-organisms, their number, morphology and activity in the soil. Work on diversity of cyanophycean algae has been carried out by several algologists (Desikachary 1959, Anand et al. 1995, Fernadez et al. 1999, Prasad and Srivastava 1992, Sen and Gupta 1998, Watanabe 1996, Tewari et al. 1999, Misra et al. 2001, Verma et al. 2002, Misra and Srivastava 2005). Role of cyanophycean algae in agriculture is well known. As heterocyst fixes nitrogen, the heterocystous forms are used as manure. Any change in morphology particularly heterocyst of cyanophycean algae due to alkalinity stress will certainly affect the nitrogen fixation capacity.

Salt affected soils are highly deficient in organic matter and nitrogen. The efficiency of applied nitrogen fertilizers is very poor due to extensive losses through volatilization in salt affected soils (Gandhi and Paliwal 1976, Rao and Batra 1983). So, algalization has a supplementing effect on the crop yield. Several trails under different agro-climatic conditions with different paddy- cultivars have shown significant increase in paddy yield due to algalization (Goyal 1993, Roger 1991, Dubey and Rai 1995, Gopalaswamy et al. 1997). Besides crop yield, 20-30 kg chemical N/ha per season can also be saved by using algal 
biofertilizer in the paddy crops (Goyal 1996, Singh et al. 1992). In the present study diversity of cyanophycean algae and changes in morphology due to highly sodic stress condition and comparison with the already reported genera were studied.

\section{MATERIALS AND METHODS}

Soil samples were collected from different places like cultivated land and barren land from Banthra, Lucknow (U.P.), India between 26, ${ }^{\circ} 40^{\prime}$ $26^{\circ}, 45^{\prime} \mathrm{N}$ latitude and $80,{ }^{\circ} 45^{\prime}-80,{ }^{\circ} 53^{\prime} \mathrm{E}$ longitude on the Lucknow-Kanpur highway at an elevation of $129 \mathrm{~m}$ above the mean sea level. The meteorological parameters indicate that the climate of the area is semi-arid, subtropical and monsoonal with an average annual rainfall of $872 \mathrm{~mm}$. The mean maximum and minimum temperatures were $39.1^{\circ} \mathrm{C}$ and $7.6^{\circ} \mathrm{C}$, respectively.

Soils were collected from two different sites, site 1 was collected from garden block of Department of Botany, University of Lucknow, Lucknow, which serves as control and site 2 was collected from Banthra which was totally barren land in which only some Callotropis procera and some grasses along with Acacia at some places were grown. The soil samples were processed for analysis and the processed samples were analyzed for different chemical characteristics of the soils viz. $\mathrm{pH}, \mathrm{EC}$, organic carbon, exchangeable cations and exchangeable sodium percentage (ESP). Soil $\mathrm{pH}$ and $\mathrm{EC}$ were determined by $\mathrm{pH}$ meter and electric conductivity meter method, respectively, in 1:2 soil water ratio (Jackson 1973). Organic C was determined by Wakley and Black's (1943) rapid titration method. Exchangeable cations and CEC were determined by ammonium acetate extractant (Bower et al. 1952). The cations extracted from soils by ammonium acetate were determined by flame photometer (Jackson 1973). Soils (5 kg in each pot) were filled in clay pots lined with polythene sheet to check the leaching of water and salts, in replicates. Water was filled in the pot. After some time, observations were taken. Algal samples were collected from each pot. Collections of algae were made by using scalpel $/ \mathrm{knife}$ and preserved in $4 \%$ formalin. For detailed study algae were stained with methylene blue and examined in Nikon Labophot-II microscope.

\section{RESULTS}

The soil analysis results showed that there were decrease in soil $\mathrm{pH}$, exchangeable $\mathrm{Na}$ and ESP and increase in organic $\mathrm{C}$ and total $\mathrm{N}$ (Fig. 1) after one year algal growth. Time to time observation revealed that there was bloomed algal growth in pot having high sodic stress which has very high $\mathrm{pH}$ (10.13), exchangeable sodium 8.46 $\mathrm{cmol} \mathrm{kg}^{-1}$ and ESP 54.5 as indicated in Table 1 while in normal soil no markable changes were observed. The microscopic study revealed that three species of Oscillatoria (Oscillatoria tenuis Ag. ex Gomont, O. limosa Ag. ex Gomont, $O$. rubescens Dc. ex Gomont), two species of Lyngbya (Lyngbya polysiphoniae Fremy, Lyngbya hieronymusii Lemm.), colony and chain of Anabena were observed in highly sodic stressed soils (Plate 1). Some morphological changes were observed in Lyngbya and Anabena (Table 2).

Table 1. Chemical properties of the soils.

\begin{tabular}{|c|c|c|}
\hline Soil Properties & Normal Soil & Sodic Soil \\
\hline Soil pH (1:2) & $7.98 \pm 0.168$ & $10.13 \pm 0.036$ \\
\hline Soil EC $\left(\mathrm{dSm}^{-1}\right)$ & $0.682 \pm 0.036$ & $0.755 \pm 0.027$ \\
\hline Org C (\%) & $0.370 \pm 0.522$ & $0.173 \pm 0.015$ \\
\hline Avail.K $\left(\mathrm{kg} \mathrm{ha}^{-1}\right)$ & $329 \pm 19.31$ & $364.5 \pm 16.67$ \\
\hline Exch. $\mathrm{Na}\left(\mathrm{c} \mathrm{mol} \mathrm{kg}{ }^{-1}\right)$ & $0.869 \pm 0.022$ & $8.46 \pm 0.243$ \\
\hline Exch. K (c mol kg-1) & $1.25 \pm 0.15$ & $0.501 \pm 0.043$ \\
\hline Exch $\mathrm{Ca}+\mathrm{Mg}\left(\mathrm{c} \mathrm{mol} \mathrm{kg}{ }^{-1}\right)$ & $12.23 \pm 0.153$ & $8.83 \pm 0.580$ \\
\hline $\mathrm{CEC}\left(\mathrm{c} \mathrm{mol} \mathrm{kg}{ }^{-1}\right)$ & $19.83 \pm 0.252$ & $15.45 \pm 0.586$ \\
\hline ESP (\%) & $4.37 \pm 0.086$ & $54.5 \pm 3.491$ \\
\hline
\end{tabular}


(a)

OBefore exp. $\quad$ A After Harvest

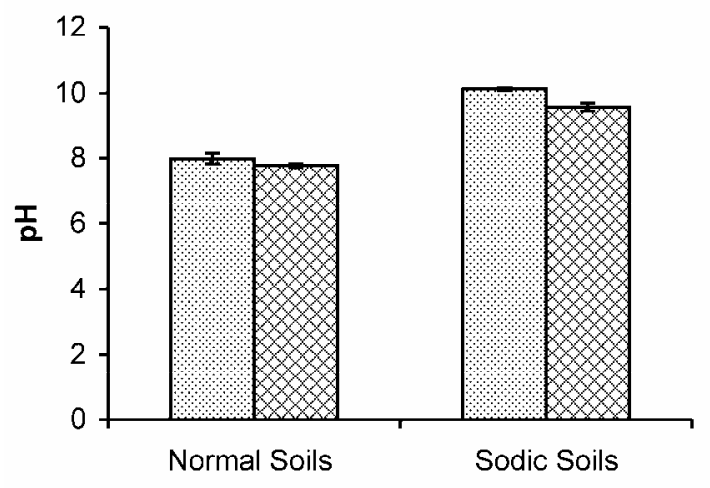

(c)

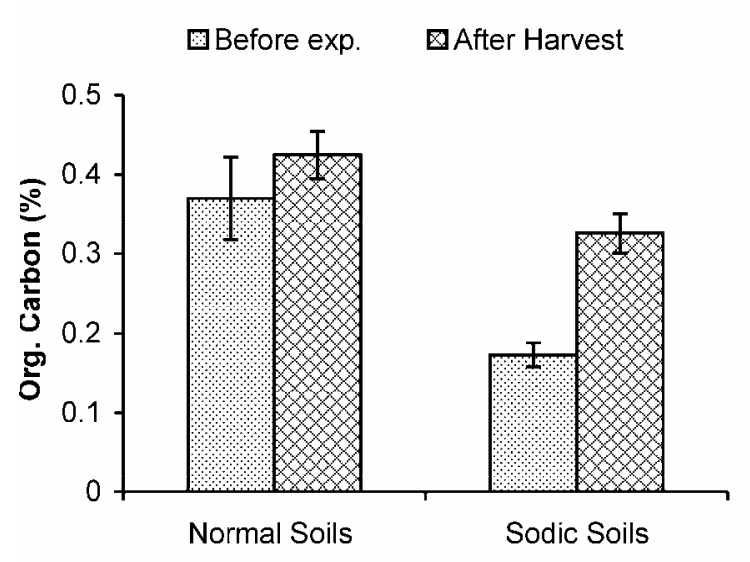

(e)

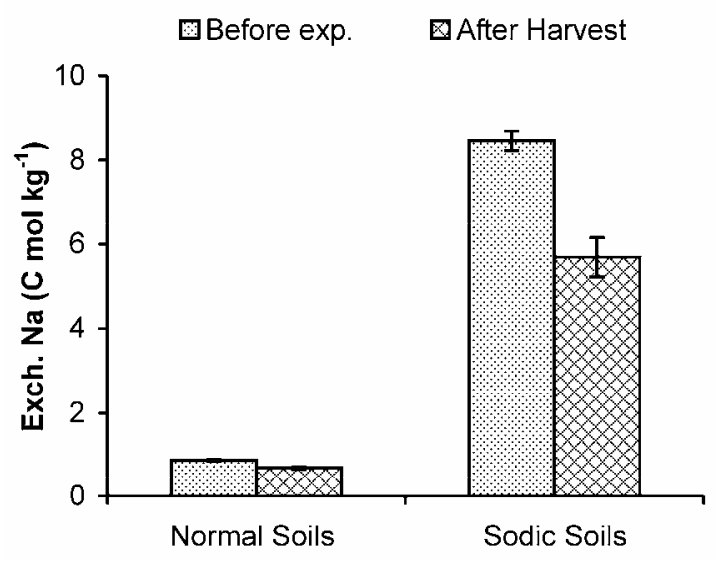

(b)

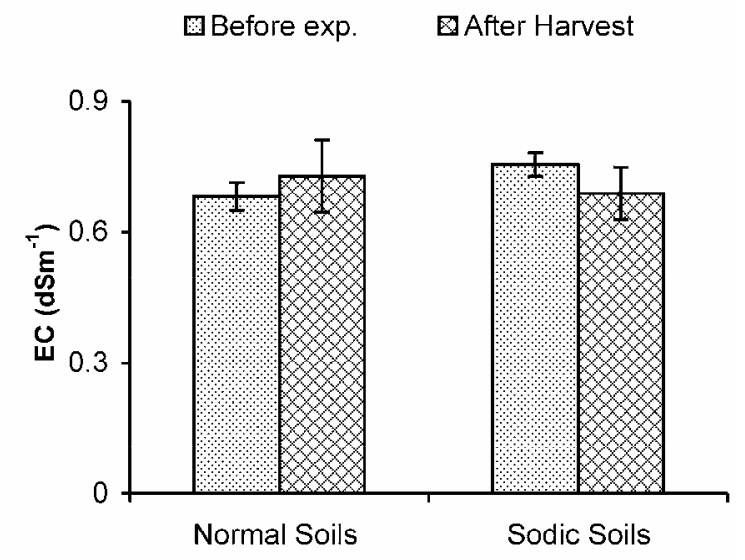

(d)

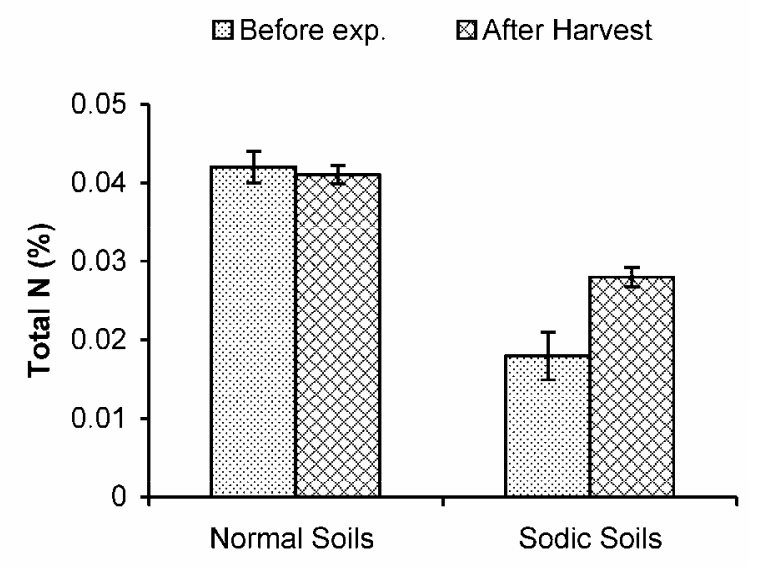

(f)

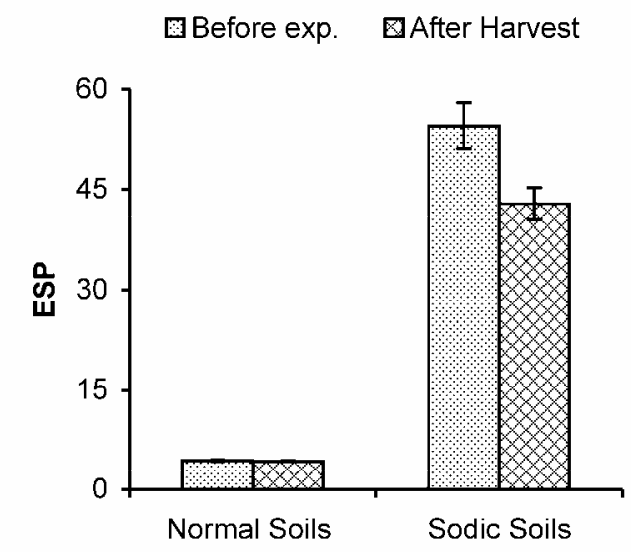

Fig. 1. Changes in chemical properties of soil before experiment and after harvesting of the algal growth: (a) soil $\mathbf{p H}$, (b) soil EC, (c) organic carbon, (d) total nitrogen in soil, (e) exchangeable $\mathrm{Na}$ in soil, (f) exchangeable sodium percentage (ESP). 

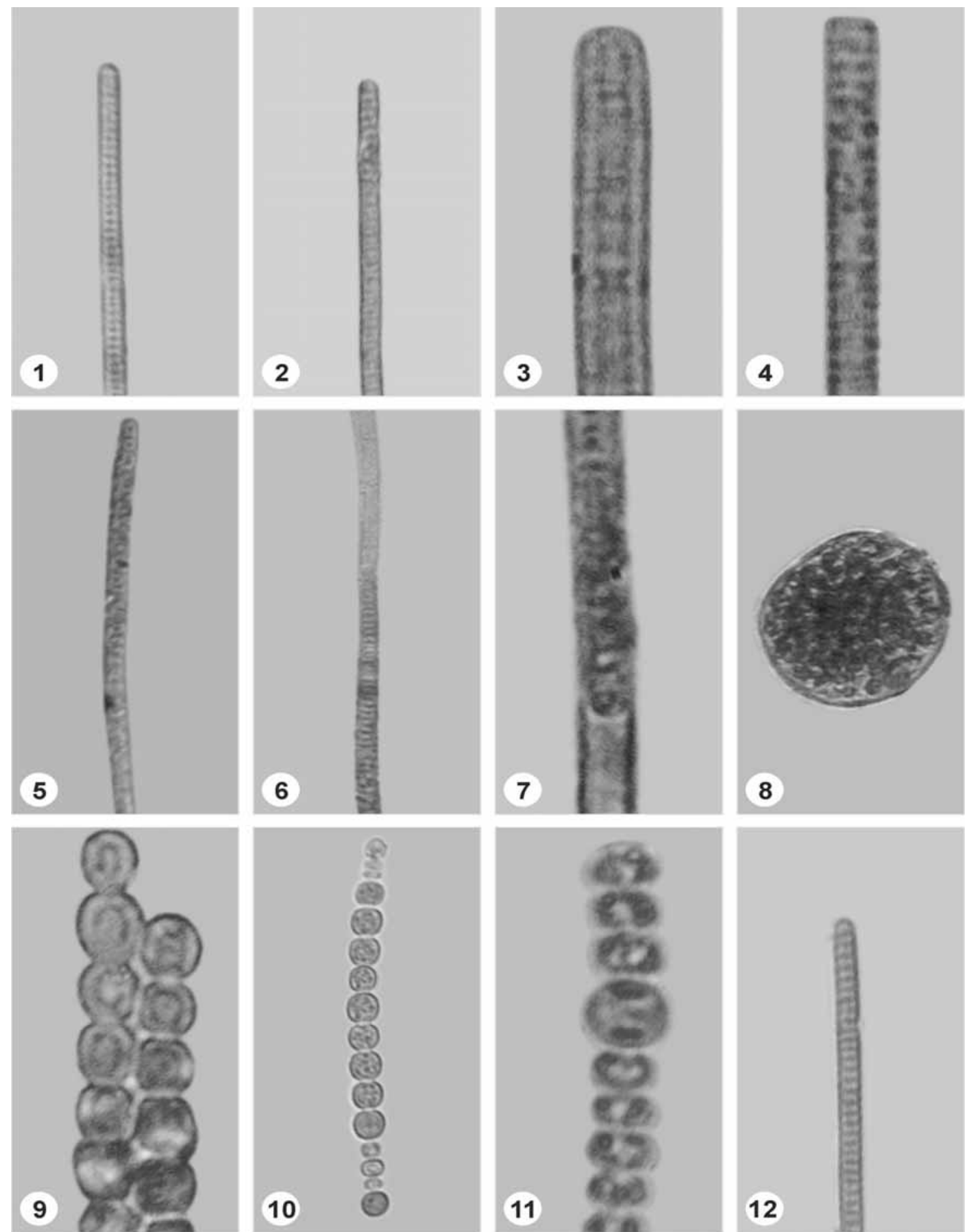

Plate 1. (1, 2: Oscillatoria tenuis Ag. ex Gomont x 1150; 3: Oscillatoria limosa Ag. ex Gomont x 1300; 4: Oscillatoria limosa Ag. ex Gomont x 750; 5: Oscillatoria rubescens Dc. ex Gomont x 800; 6: Lyngbya polysiphoniae Fremy x 1000; 7: Lyngbya hieronymusii Lemm.x 1400; 8: Colony of Anabaena Bory x 650; 9: Heterocyst chain of Anabaena Bory; 10: Anabaena orientalis Dixit x 1000; 11: Anabaena orientalis Dixit x 2000; 12: Oscillatoria tenuis Ag. ex Gomont x 1150). 
Table 2. Morphological observation of cyanophycean algae in sodic stress soils and comparison with normal condition.

\begin{tabular}{|c|c|c|}
\hline Species & $\begin{array}{l}\text { Reported in normal condition } \\
\text { (Desikachary 1959) }\end{array}$ & In present study \\
\hline $\begin{array}{l}\text { Oscillatoria tenuis Ag. ex Gomont } \\
\text { (Plate-1; Figs. } 1,2,12 \text { ) }\end{array}$ & Cell $\mathrm{L}=2-5 \mu \mathrm{m}, \mathrm{W}=5-6.5 \mu \mathrm{m}$ & Cell $\mathrm{L}=2-2.5 \mu \mathrm{m}, \mathrm{W}=4-5 \mu \mathrm{m}$ \\
\hline $\begin{array}{l}\text { O. limosa Ag. ex Gomont } \\
((\text { Plate-1; Figs. 3,4) }\end{array}$ & Cell $\mathrm{L}=2-5 \mu \mathrm{m}, \mathrm{W}=13-16 \mu \mathrm{m}$ & Cell $\mathrm{L}=5-6 \mu \mathrm{m}, \mathrm{W}=10-12 \mu \mathrm{m}$ \\
\hline $\begin{array}{l}\text { O. rubescens Dc. ex Gomont } \\
\text { (Plate-1; Fig. 5) }\end{array}$ & Cell $\mathrm{L}=2-4 \mu \mathrm{m}, \mathrm{W}=6-8 \mu \mathrm{m}$ & Cell L $=3-4 \mu \mathrm{m}, \mathrm{W}=5 \mu \mathrm{m}$ \\
\hline Lyngbya polysiphoniae Fremy & Cell $\mathrm{L}=1 \mu \mathrm{m}, \mathrm{W}=2 \mu \mathrm{m}$ & Cell $\mathrm{L}=2 \mu \mathrm{m}, \mathrm{W}=4 \mu \mathrm{m}$ \\
\hline (Plate-1; Fig. 6) & Filament $\mathrm{W}=4 \mu \mathrm{m}$ & Filament $\mathrm{W}=5 \mu \mathrm{m}$ \\
\hline Lyngbya hieronymusii Lemm. & Cell $\mathrm{L}=2.5-4 \mu \mathrm{m}, \mathrm{W}=11-13 \mu \mathrm{m}$ & Cell $\mathrm{L}=6 \mu \mathrm{m}, \mathrm{W}=10 \mu \mathrm{m}$ \\
\hline (Plate-1; Fig. 7) & Filament $\mathrm{W}=12-14 \mu \mathrm{m}$ & Filament $\mathrm{W}=14 \mu \mathrm{m}$ \\
\hline $\begin{array}{l}\text { Colony of Anabena Bory } \\
\text { (Plate-1; Fig. 8) }\end{array}$ & Absent & Colony dia. $=50-55 \mu \mathrm{m}$ \\
\hline $\begin{array}{l}\text { Heterocyst chain of Anabena Bory } \\
\text { (Plate-1; Fig. 9) }\end{array}$ & Absent & Present \\
\hline Anabena orientalis Dixit & Cell $\mathrm{L}=3.7-4.8 \mu \mathrm{m}, \mathrm{W}=2.5-4 \mu \mathrm{m}$ & Cell $\mathrm{L}=5 \mu \mathrm{m}, \mathrm{W}=5-5.5 \mu \mathrm{m}$ \\
\hline \multirow[t]{4}{*}{ (Plate-1; Figs. 10,11) } & Akinete $\mathrm{L}=14.8-16.6 \mu \mathrm{m}$ & Akinete $\mathrm{L}=8.5 \mu \mathrm{m}$ \\
\hline & $\mathrm{W}=7.4-9.2 \mu \mathrm{m}$ & $\mathrm{W}=8 \mu \mathrm{m}$ \\
\hline & Heterocyst $\mathrm{L}=7.4-9.2 \mu \mathrm{m}$ & Heterocyst $\mathrm{L}=8 \mu \mathrm{m}$ \\
\hline & $\mathrm{W}=4.8-5.5 \mu \mathrm{m}$ & $\mathrm{W}=9 \mu \mathrm{m}$ \\
\hline
\end{tabular}

$\mathrm{L}=$ Length, $\mathrm{W}=$ Width, dia. $=$ Diameter

\section{DISCUSSION AND CONCLUSION}

Calcium carbonate is invariably present in alkali soils. Under favorable conditions, microbiological decomposition of organic matter added by pioneer colonizers like blue green algae (BGA) initiate natural reclamation (Singh 1950) through production of organic acids, which react with calcium carbonate, releasing calcium that in turn replaces the sodium of the exchange complex. There are report on the use of BGA as agent for reclamation of alkali soils due to their ability to secret organic acids and immobilized sodium in the biomass (Singh 1950, Subhashini and Kaushik 1985). Similar observations were found in present study which was change in chemical properties of the soils. These algae have capacity to reclaim "usar soil" through a series of successive algal growth in a water logged condition as indicated by several workers and in present study also. One of the important observations regarding morphology of BGA in the present study, showed differences in length and width of cell in comparison with normal condition which may be due to sodic stress condition. Besides the morphological observation, authors have also recorded several heterocysts, in the form of chain (Plate 1, Fig. 9). The presence of heterocysts chain in sodic stress soils will certainly fix high atmospheric $\mathrm{N}_{2}$ in comparision to normal one, because these heterocysts are important site of nitrogen fixation and thus increase soil fertility. However, non-heterocystous forms also fix $\mathrm{N}_{2}$ usually under aerobic condition (eg. Oscillatoria). On the surface of saline "usar soil" BGA developed during rainy season, form thick stratum 
of Anabaena (Plate 1; Figs. 10, 11) and Oscillatoria (Plate 1; Figs. 1-5, 12). The present study of one year experiments clearly shows the sodic land reclamation is possible by growing these species of BGA in sodic land in successive years.

\section{ACKNOWLEDGEMENTS}

Authors are thankful to Department of Science and Technology, New Delhi for financial assistance through SERC Fast Track Scheme (SR/FT/L-172/2004).

\section{REFERENCES}

Anand, N., R.S. Sharma and H. Kumar. 1995. Distribution of blue green algae in rice field of Kerala State, India. Phykos 34(1\&2):55-64.

Bower, C.A., R.F. Reitemeir and M. Fireman. 1952. Exchangeable cation analysis of saline and alkali soils. Soil Science 73:251-261.

Desikachary, T.V. 1959. Cyanophyta: I.C.A.R. monograph on algae, New Delhi, India, 686pp.

Dubey, A.K. and A.K. Rai. 1995. Application of algal biofertilizers (Aulosira fertilissima var. tenuis and Anabaena doliolum Bharadwaja ) for sustained paddy cultivation in Northern India. Israel Jour. of Plant Sc. 43:41-55.

Fernadez, B., C. Maria and S.V. Maria. 1999. Taxonomic and ultrastructural aspect in Oscillatoria acuta, O. animalis, O. proteus, Cyanophyta hormogoniales. Archiv fur Hydrobiol. Supp. 124(0):12-14.

Gandhi, A.P. and K.V. Paliwal. 1976. Mineralization and gaseous losses of nitrogen from urea and ammonium sulphate in salt affected soils. Plant and Soil 45:247-255.

Gopalasawamy, G., S.R. Anthoni and T.B. Ranganathan. 1997. Biofertilizer application strategy to rice (Oryza sativa). Indian Journal of Agronomy 42(1):68-73.
Goyal, S.K. 1993. Algal biofertilizer for vital soil and free nitrogen. Proc. Indian Nat. Sci. Acad. B. 59:295.

Goyal, S.K. 1996. Sustainability in rice cultivation through algal biofertilizer. Agrochemical and sustainable agriculture, Ed. N.K. Roy, A.P.C. Publ. Pvt. Ltd., New Delhi, India, 161-172pp.

Jackson, M.L. 1973. Soil Chemical Analysis. Pentice Hall of India Pvt. Ltd., New Delhi.

Misra, P.K. and A.K. Srivastava. 2005. Fresh water cyanophycean algae from North Eastern Uttar Pradesh, India. Jour. Ind. Bot. Soc. 84:67-75.

Misra, P.K., J. Prakash, A.K. Srivastava and S. Kishore. 2001. Some blue green algae from Basti, U.P. Biol. Memoirs 27(1):32-37.

Prasad, B.N. and M.N. Srivastava. 1992. Fresh water algal flora of Andaman and Nicobar Islands (Vol. I). Publ. B. Singh and M.P. Singh, Dehradun, India, 369 pp.

Rao, D.L.N. and L. Batra. 1983. Ammonia volatilization from applied nitrogen in alkali soils. Plant and Soil 70:219-28.

Roger, P.A. 1991. Blue green algae in agriculture. In: Microorganism that Promote Plant Productivity. (eds.) Dawson, J.O. and P.J. Dart. Kluwer, Dardrecht.

Sen, C.R. and D. Gupta. 1998. The genus Oscillatoria Vaucher from lower Gangatic plain of West Bengal. Phykos 37(162):89-93.

Singh, A.N., S.K. Sinha, V.P. Pandey, A.K. Dubey and D.C. Verma. 1992. Effect of blue green algae inoculation on yield of paddy in different district of U.P. New Agriculturist 3(2):189192. 
Singh, R.N. 1950. Reclamation of usar lands in India through blue green algae. Nature 165:325-326.

Subhashini, D. and B.D. Kaushik. 1985. Amelioration of sodic soils with blue green algae. Australian Journal Soil Research 19:361-366.

Tewari, O.N., B.V Singh, D. Wattaldhar and P.K. Singh. 1999. Blue green algae of Arid Zone. Phykos 38(1\&2):109-111.

Verma, D.C., R.K. Mehrotra, P.K. Misra and M.N. Srivastava. 2002. Observation on certain blue green algae from polluted environment. Geophytology 28(162):57-63.

Wakley, A. and I.A. Black. 1943. An examination of the Degtejareff method for determining soil organic matter and a proposed modification of the chromic acid titration method. Soil Science 37:29.

Watanabe, M. 1996. Studies on planktonic blue green algae. Anabaena pseudocompacta sp. nov. from eutrophic lake in central Japan. Bull. of the National Science Museum Series B. 22(3):93-97. 